\title{
The environmental and energy policies to enable sustainable consumption and production in the Gulf Cooperation Council countries
}

\author{
Osama D. Sweidan ${ }^{1}$
}

Received: 23 July 2020 / Accepted: 25 July 2021 / Published online: 31 July 2021

(c) The Author(s), under exclusive licence to Springer-Verlag GmbH Germany, part of Springer Nature 2021

\begin{abstract}
Sustainable consumption and production mean that economic development should satisfy the needs of the current population without jeopardizing the lives of future generations. Relying on the hydrocarbon sector generates a significant trade-off between economic development and the environment. The GCC governments have an essential role in this process and can affect the outcomes. The policies that have been implemented in the GCC countries to protect the environment and empower sustainable consumption and production were explored and identified. Moreover, the success of these policies in achieving their goals was assessed. The analytical approach and utilizing the previous studies' findings were used by the current study. This study finds that the institutional actions of the Gulf countries are not enough to generate sustainable consumption and production. These countries remain strongly affected by the hydrocarbon sector, and the diversification achievements are weak. Further, the energy price reforms have many problems as a tool to enhance sustainable consumption and production. Additionally, these countries work under the concept of entrepreneurial state capitalist. The government controls all the sectors, including the private sector, to secure the regime. The policy implication of the current paper is that the GCC countries should recover the process of diversifying the economy, enhancing the movements toward the free market economy, and adopting an efficient energy-environmental policy by enhancing more concrete actions toward new technologies. It includes shifting to renewable energy, i.e., solar and wind.
\end{abstract}

\section{Graphic abstract}

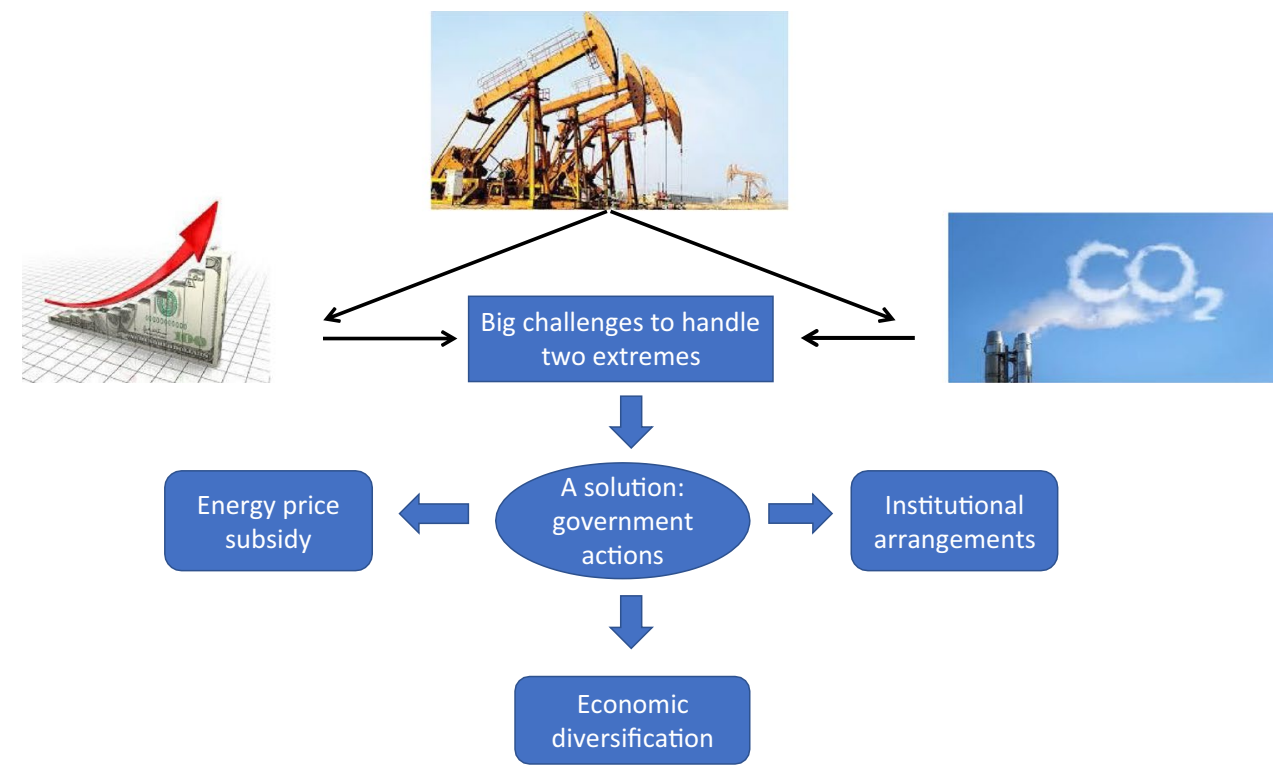

Extended author information available on the last page of the article 
Keywords Sustainable development - Environment protection · Economic diversification - Energy price reforms · Government policies · The GCC countries

JEL Classifications Q01 $\cdot \mathrm{Q} 35 \cdot \mathrm{Q} 48 \cdot \mathrm{Q} 58$

\section{Introduction}

Sustainable economics is an old economic branch that focuses on allocating limited resources to satisfy unlimited wants, desires, and needs. The concern about economic sustainability is growing very fast because of the various economic shocks and global environmental threats, i.e., climate change. Hence, the concept of sustainability becomes broader. Baumgartner and Quaas (2010) define sustainability economics as being ethically founded in the idea of not wasting scarce resources while achieving the two normative goals of (1) the fulfilling of the desires of the current population, and (2) justice, including justice between the present and future generations and justice toward nature. Likewise, Sabapathy (2007) defines it as a permanent economic and social improvement that respects the limits of the Earth's ecologies and meets the needs and aspirations of everyone for better life quality, now and for future generations.

On September 25, 2015, the United Nations (UN) adopted the 2030 universal agenda for sustainable development (Walsh et al. 2020). It is an action plan for people, the planet, and prosperity. The agenda seeks to attain sustained and inclusive economic growth, social development, environmental protection, and combat poverty and hunger. It has 17 sustainable development goals and 169 targets. Goal 12 talks about ensuring sustainable consumption and production (SCP) patterns (Walsh et al. 2020). SCP can be defined as "the use of services and related products, which respond to basic needs and bring a better quality of life while minimizing the use of natural resources and toxic materials as well as the emissions of waste and pollutants over the life cycle of the service or product so as not to jeopardize the needs of further generations" (Baker 1996). Sustainability has been highlighted because of the high expected demand for natural resources during the next two decades. More people are expected to join the middle class. Hence, changing consumption and production patterns are necessary conditions to preserve the earth's environment and guarantee sustainable economics. The change includes reducing food waste, agricultural products, polluting water, reducing $\mathrm{CO}_{2}$ emissions per capita, and using efficient energy tools. The UN data show that the world is wasting around USD 1 trillion of food per year, and it can save USD 120 billion annually if the globe switch to more efficient energy use.

Bengtsson et al. (2018) recognize two distinct views from the SCP literature to achieve sustainable consumption. The first approach relies on promoting more efficient production methods, i.e., technological improvement and well-informed consumers. The second approach calls for reducing the aggregate consumption level, addressing the income distribution, and adopting social and institutional reforms. Overall, they believe that a successful method to achieve sustainable consumption is to combine the two approaches.

The Intergovernmental Panel on Climate Change (IPCC) has published many reports about climate change during the past years (IPCC 2018). All the reports confirm that global warming is a remarkable fact, leading to severe problems, i.e., raising the temperature of lands, oceans, and creating heat waves. These dangerous developments will increase poverty and starvation levels, and human health suffers. The reports warn the Middle East and North Africa (MENA) region from a high risk of drought if the temperature in the region increased by more than $1.5^{\circ}$. The Arab Forum for environment and development (AFED) confirms the low air quality in the Gulf Cooperation Council (GCC) countries. These countries include Bahrain, Kuwait, Oman, Qatar, Saudi Arabia, and the United Arab Emirates.

The GCC countries rely heavily on oil and gas exports as a primary source of income. The British petroleum statistical review of the world energy for 2020 reports that these countries own around $30.5 \%$ and $19.6 \%$ of the world's proven oil and gas reserves, respectively. These countries employ oil and gas sales revenues to boost economic development, improve social and health indicators, and build a first-class infrastructure. Additionally, energy prices for domestic consumption are the lowest globally, which motivates an excessive energy consumption pattern, influences the economic structure, and threatens the environment. The global ecological footprint is a valuable indicator to understand environmental threats. The average consumption ecological footprint of the GCC countries ( $8.9 \mathrm{gha} /$ person) in 2019 is higher than that of the world average $(2.75 \mathrm{gha} /$ person). During the past five decades, each GCC country has articulated a development strategy based on diversifying the economy to increase production, competitiveness, and move away from the hydrocarbon sector. Over time, job creation for nationals was among the priorities because of oil price fluctuations. Recently, the GCC countries add energy price reforms to the agenda. Further, the energy consumption per capita in the GCC countries is high but vital for economic growth. Unfortunately, it led to a high level of $\mathrm{CO}_{2}$ emissions per capita.

These facts present a noticeable gap or question in the literature. Why are the GCC countries unable to achieve the SCP patterns? This question motivated our paper. It is critical to understand where the GCC countries' policies and actions stand and why they failed in their mission. Thus, our paper contributes by providing 
a comprehensive review and understanding of the policies in the area of SCP. These policies are crucial to create a balance between achieving permanent economic growth and preserving the environment. The paper's goals are to identify the environmental challenges and explore the GCC governments' policies to protect the environment and enable the SCP. Moreover, we explain why these policies did not succeed in accomplishing their goals. We focus on the policies related to the energy and environment sector. The GCC countries' historical economic model is the allocation state model. It gives the government a significant role in steering the economy.

The current paper uses two methodologies. First, the analytical approach breaks down the GCC policies into sub-sectors to analyze and understand them. Second, we utilize data, remarks, and findings of the previous academic studies to use and connect them in the analytical approach to expand the knowledge and extract results. The analytical approach is useful to explore economic and social problems. It helps to look much deeper into the problem, understand its root causes, its consequences, and how to resolve it. The remaining of the article is organized as follows. Section 2 presents some facts about the GCC countries' energy consumption, production, and $\mathrm{CO}_{2}$ emissions per capita. Section 3 reviews the relevant literature about the relationships between economic growth, energy consumption, and the environment in the GCC countries. Section 4 introduces the GCC governments' actions and policy framework. Section 5 discusses the GCC economic system; moving to the market-based model or changing the government role. Summary and conclusions are made in Sect. 6.

\section{GCC countries: energy consumption, production, and $\mathrm{CO}_{2}$ emissions per capita}

The GCC states are a homogenous group with their economic resources, tribal, cultural, and religious identities. They have a problem of water scarcity and desertification; thus, they rely on water desalination. The water problem becomes more evident than before when the analysis sheds light on the demographic changes. The population number of the group is approximately 58.0 million inhabitants in 2019, which is around $11.0 \%$ of the MENA population. The annual average population growth rate is high and reached 4.1\% during the period (1975-2019). The high energy consumption and production per capita in the GCC countries are stimulated by the high annual population growth rate, water desalination, low energy prices, and high economic growth rate. The World Bank development indicators (WBDI) illustrate that the average real economic growth of the GCC states is about $4.0 \%$ during the period (1995-2019).

The available data prove the massive energy consumption and $\mathrm{CO}_{2}$ emission per capita in the region. Table 1 reveals and contrasts the GCC countries' energy use with three industrial countries, Japan, France, and the UK, during the period (1971-2014). The comparison displays a high energy consumption per capita of the GCC states relative to the industrial economies. The GCC group energy consumption is 2.3 times more than that of the industrial countries. This divergence opens an essential question about the efficient use of energy in the GCC states. Abdel Gelil (2017) states that the Arab countries have been characterized as one of the least energy-efficient regions globally. Table 2 introduces the GCC countries' electricity consumption (kW. h) per capita and compares it with that of the three industrial countries during the period (1975-2014). The electricity consumption increased by almost six times during the past four decades in the GCC countries. Further, the electricity consumption per capita in the GCC states is larger than that of the individual industrial countries by around 1.50 times.

The historical low energy prices, high economic growth rates, and demographic movements have led to massive pressures on the environment, i.e., increasing levels of $\mathrm{CO}_{2}$ emissions per capita. The WBDI display that the GCC states' average contribution to the world $\mathrm{CO}_{2}$ emissions reached $1.78 \%$ during the period (1971-2014), but this contribution expanded to $2.49 \%$ during the period (2000-2014). Table 3 illustrates and compares the $\mathrm{CO}_{2}$ emissions per capita between the GCC countries and the three industrial countries. The $\mathrm{CO}_{2}$ emissions have a remarkable increase
Table 1 Energy use (kg of oil equivalent per capita) of the individual GCC countries and three industrial countries (in thousands). Source: World Bank Development Indicators via the Data Stream

\begin{tabular}{lrrrrlrlll}
\hline Years & Bahrain & Kuwait & Oman & Qatar & Saudi Arabia & UAE & Japan & France & UK \\
\hline 1971 & 6.39 & 7.64 & 0.11 & 7.75 & 1.21 & 3.63 & 2.53 & 3.02 & 3.73 \\
1980 & 7.80 & 7.62 & 1.00 & 14.80 & 3.19 & 6.94 & 2.95 & 3.47 & 3.52 \\
1985 & 9.92 & 8.07 & 1.41 & 15.22 & 3.49 & 9.86 & 3.01 & 3.59 & 3.55 \\
1990 & 10.56 & 4.34 & 2.33 & 13.70 & 3.55 & 10.98 & 3.55 & 3.83 & 3.60 \\
1995 & 11.41 & 9.18 & 2.77 & 15.87 & 4.51 & 11.31 & 3.94 & 3.98 & 3.73 \\
2000 & 11.99 & 9.13 & 3.34 & 18.44 & 4.71 & 9.99 & 4.08 & 4.14 & 3.79 \\
2005 & 11.68 & 11.54 & 3.94 & 19.27 & 5.13 & 9.72 & 4.06 & 4.29 & 3.69 \\
2010 & 10.21 & 10.70 & 6.15 & 15.53 & 6.76 & 7.46 & 3.89 & 4.02 & 3.23 \\
2014 & 10.59 & 8.96 & 6.14 & 18.56 & 6.94 & 7.77 & 3.47 & 3.66 & 2.78 \\
Avg & 10.07 & 8.10 & 2.77 & 15.54 & 4.12 & 8.58 & 3.45 & 3.76 & 3.57 \\
\hline
\end{tabular}


over the time horizon. It is almost increased by nine times during the past four decades. On average, the $\mathrm{CO}_{2}$ emission per capita in these countries is higher by three times than that of industrial countries.

The GCC energy pricing policies play a crucial role in encouraging the consumption pattern and increasing $\mathrm{CO}_{2}$ emissions. These countries adopted programs of subsidizing energy and food. As a result, their energy prices are the lowest in the world. The term subsidy is the financial support that developers (producers) or consumers receive from governments, leading to lower prices (Wei et al. 2021). In 2015, the GCC countries started to abolish the subsidy. Figures 1 and 2 introduce and compare electricity and gasoline prices in 2019 between the GCC countries and Arab and industrial
Table 2 Electricity

consumption (kW. h) per capita of the individual GCC countries and three industrial countries (in thousands). Source: World Bank Development Indicators via the Data Stream
Table $3 \mathrm{CO}_{2}$ emissions per capita ( $t$ ) of the individual GCC countries and three industrial countries. Source: World Bank Development Indicators via the Data Stream. Data for France is available for 2014 only

\begin{tabular}{lcccrlrlll}
\hline Years & Bahrain & Kuwait & Oman & Qatar & Saudi Arabia & UAE & Japan & France & UK \\
\hline 1975 & 2.63 & 4.17 & 0.15 & 3.80 & 0.53 & 2.32 & 4.03 & 3.25 & 4.49 \\
1980 & 4.61 & 6.06 & 0.62 & 9.72 & 1.97 & 5.75 & 4.72 & 4.42 & 4.68 \\
1985 & 15.93 & 8.17 & 1.47 & 10.07 & 3.07 & 8.63 & 5.33 & 5.26 & 4.83 \\
1990 & 15.62 & 8.22 & 2.19 & 9.59 & 4.02 & 8.50 & 6.81 & 5.97 & 5.36 \\
1995 & 20.55 & 13.15 & 2.58 & 10.74 & 4.93 & 9.40 & 7.70 & 6.62 & 5.58 \\
2000 & 20.01 & 14.07 & 3.20 & 14.35 & 5.66 & 12.31 & 8.30 & 7.22 & 6.11 \\
2005 & 21.33 & 17.08 & 3.92 & 15.46 & 6.62 & 12.28 & 8.54 & 7.65 & 6.27 \\
2014 & 19.60 & 15.59 & 6.45 & 14.78 & 9.40 & 11.09 & 7.82 & 6.94 & 5.13 \\
Avg & 15.40 & 11.57 & 2.78 & 11.53 & 4.79 & 9.04 & 6.85 & 6.19 & 5.40 \\
\hline
\end{tabular}

\begin{tabular}{lllrllllll}
\hline Years & Bahrain & Kuwait & Oman & Qatar & Saudi Arabia & UAE & Japan & France & UK \\
\hline 1971 & 13.80 & 33.88 & 2.80 & 76.64 & 9.80 & 75.98 & 7.55 & 8.81 & 11.82 \\
1975 & 21.59 & 16.42 & 8.23 & 66.64 & 11.22 & 56.05 & 7.77 & 8.24 & 10.74 \\
1980 & 21.92 & 17.98 & 5.24 & 58.53 & 17.39 & 35.40 & 8.11 & 9.13 & 10.29 \\
1985 & 24.31 & 16.77 & 5.78 & 33.43 & 13.09 & 35.89 & 7.58 & 7.06 & 9.90 \\
1990 & 25.06 & 24.29 & 6.28 & 24.71 & 11.38 & 27.96 & 8.87 & 6.42 & 9.71 \\
1995 & 26.29 & 34.04 & 7.21 & 61.91 & 12.55 & 28.85 & 9.43 & 5.86 & 9.28 \\
2000 & 28.05 & 26.12 & 9.65 & 58.64 & 14.3 & 35.68 & 9.62 & 5.95 & 9.2 \\
2005 & 21.60 & 31.43 & 11.90 & 58.92 & 16.63 & 25.36 & 9.70 & 6.10 & 8.98 \\
2010 & 23.59 & 29.89 & 15.59 & 40.74 & 18.91 & 19.44 & 9.15 & 5.43 & 7.86 \\
2014 & 23.45 & 25.22 & 15.44 & 45.42 & 19.53 & 23.30 & 9.54 & 4.57 & 6.50 \\
2016 & 22.23 & 24.95 & 14.17 & 38.90 & 17.37 & 22.04 & 8.94 & NA & 5.78 \\
Avg & 23.57 & 23.76 & 9.03 & 52.29 & 14.88 & 34.46 & 8.77 & 6.85 & 9.34 \\
\hline
\end{tabular}

Fig. 1 Prices of electricity in the GCC and other countries (USD per kW. h), 2019. Source The global economy website

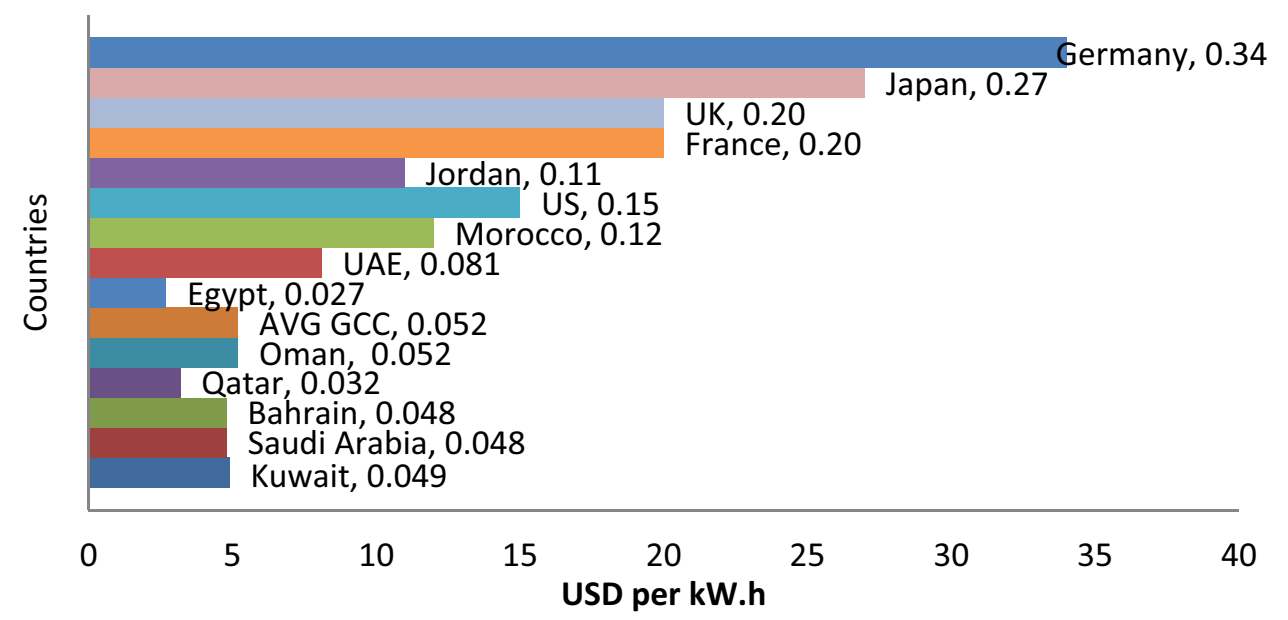


Fig. 2 Pump prices for gasoline in the GCC and other countries (USD per L), 2019. Source The global economy website

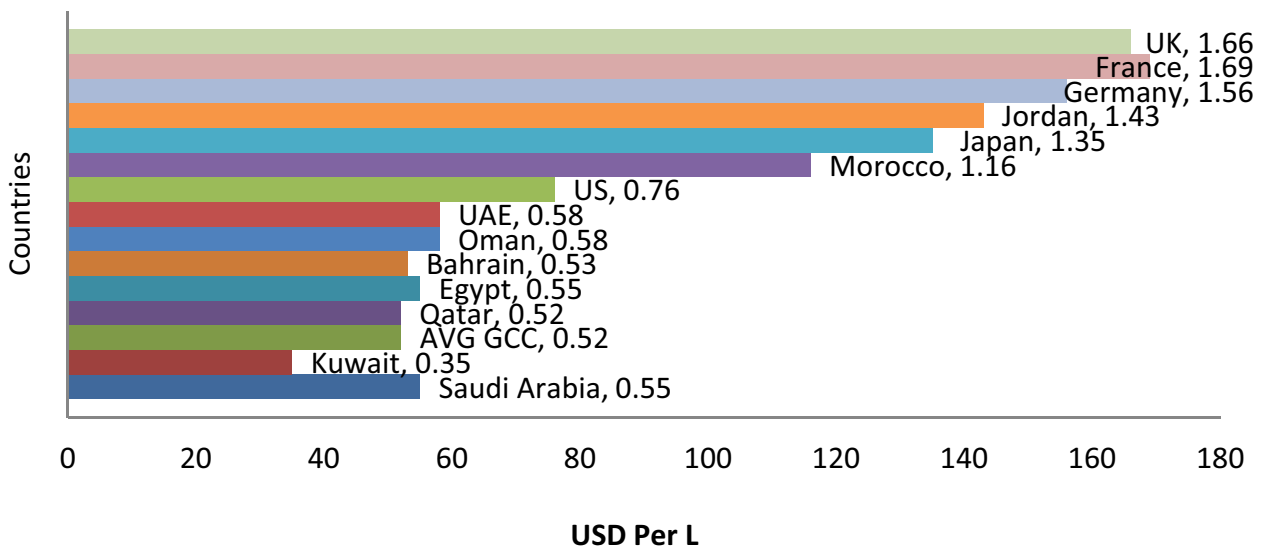

countries. We report the GCC countries' prices after removing almost half of the subsidy. Indeed, these countries have the lowest energy prices, even without half of the subsidy.

Moreover, oil revenues contribute positively to economic development and public welfare in the area. The human development index (HDI) increased remarkably from 0.73 in 1990 to 0.84 in 2018. Besides, the average relative importance of health expenditure to GDP reached $3.22 \%$ during the period (2000-2016). Accordingly, the life expectancy at birth expanded from 60.3 years in 1970 to 77.2 years in 2018 .

\section{Literature review: the previous empirical works}

The literature has extensive empirical works on the relationship between energy consumption, economic growth, and the environment. Tiba and Omri (2017) perform a comprehensive literature survey on this strand of research. Likewise, Kais and Sami (2016) brief around 27 studies from the same research area. Tiba and Omri (2017) summarize the main conclusions of approximately 400 studies. Remarkably, they report only two studies (Al-Iriani 2006; Salahuddin and Gow 2014), which examine the link between these variables in the GCC countries. They also report two single studies about Saudi Arabia, (Alkhathlan et al. 2012; Alkhathlan and Javid 2013), and one single study about the UAE, (Shahbaz et al. 2014). The empirical research on economic growth, energy consumption, and the environment can be divided into three different spectrums: first, examining the relationship between energy indicators and economic growth, second, investigating the existence of the environmental Kuznets curve (EKC), and third, exploring the relationship between economic growth, energy consumption, and $\mathrm{CO}_{2}$ emissions. Muhammed (2019) performs a recent study including a sample of 68 countries, of which MENA countries.
Based on our knowledge, we compile all the previous empirical studies, which investigate the relationships between energy consumption, economic growth, and the environment of the GCC countries. Most of these studies concentrate on exploring the causality relationship between the variables. Causality relationships fall into four types. First, a unidirectional causality running from energy consumption to real output "the growth hypothesis." Thus, any constraint on energy use may negatively affect the real economy. Second, a unidirectional causality from real output to energy consumption "the conservation hypothesis." In this case, the government can adopt a conservative policy of energy consumption without a significant influence on real output. Third, a bidirectional relationship; it means that economic growth and energy consumption are jointly determined "the feedback hypothesis." Fourth, there is no causality between economic growth and energy consumption "the neutral hypothesis"; thus, policy implication does not exist.

Table 4 presents the previous empirical studies concerning the GCC area. The number of studies in this research area is limited, and most of them initiated in the last decade. These studies show a significant relationship between economic growth, energy consumption, and $\mathrm{CO}_{2}$ emissions . Some studies confirm a bidirectional causality relationship, while others prove a unidirectional causality. Based on the results, the GCC countries should adopt conservative energy policies. The policymakers should understand the type of link between economic growth and energy consumption in each country fully. Among the previous empirical studies, there are two empirical studies, (Sweidan 2018; Sweidan and Alwaked 2016), which explore the impact of economic development on economic sustainability. Those two studies conclude that GCC economic development increases environmental stress. In the same vein, Al-Mulali and Ozturk (2015) and Mahmood et al. (2020) find that energy consumption, urbanization, trade openness, and industrial development increase environmental damage. 
Table 4 A summary of the previous studies in the MENA and GCC countries. Source: compiled by the author

\begin{tabular}{|c|c|c|c|c|c|}
\hline No. & Study & Countries & Period & Methodology & Results \\
\hline 1 & Mahmood et al. (2020) & Saudi Arabia & 1968-2014 & ARDL model & $\begin{array}{l}\text { Industrialization and urbaniza- } \\
\text { tion impede the environment }\end{array}$ \\
\hline 2 & Sweidan (2018) & 13 MENA countries & 1995-2013 & Panel analysis & $\begin{array}{l}\text { The economic performance or } \\
\text { economic sectors increases } \\
\text { environmental stress (EIWB) }\end{array}$ \\
\hline 3 & Sbia et al. (2017) & UAE & 1975-2011 & $\begin{array}{l}\text { ARDL model and VECM } \\
\text { Granger causality }\end{array}$ & $\begin{array}{l}\text { A bidirectional causality } \\
\text { between electricity consump- } \\
\text { tion and economic growth. } \\
\text { The EKC hypothesis exists in } \\
\text { the UAE }\end{array}$ \\
\hline 4 & $\begin{array}{l}\text { Sweidan and Al Waked } \\
\text { (2016) }\end{array}$ & The GCC countries & 1995-2012 & Panel analysis & $\begin{array}{l}\text { The economic development } \\
\text { increases environmental stress } \\
\text { (EIWB) }\end{array}$ \\
\hline 5 & $\begin{array}{l}\text { Al-Iriani and Trabelsi } \\
\text { (2015) }\end{array}$ & The GCC countries & 1980-2011 & $\begin{array}{l}\text { Time series and panel } \\
\text { analyses }\end{array}$ & $\begin{array}{l}\text { Causality relationships exist, } \\
\text { but not homogeneous in all } \\
\text { countries }\end{array}$ \\
\hline 6 & $\begin{array}{l}\text { Al-Mulali and Ozturk } \\
\text { (2015) }\end{array}$ & 14 MENA countries & 1996-2012 & $\begin{array}{l}\text { Panel analysis and the fully } \\
\text { modified ordinary least } \\
\text { square (FMOLS) }\end{array}$ & $\begin{array}{l}\text { Energy consumption, urbani- } \\
\text { zation, trade openness and } \\
\text { industrial development } \\
\text { increase environmental dam- } \\
\text { age }\end{array}$ \\
\hline 7 & $\begin{array}{l}\text { Salahuddin and Gow } \\
\text { (2014) }\end{array}$ & The GCC countries & $1980-2012$ & Granger causality test & $\begin{array}{c}\text { The economic growth does not } \\
\text { Granger cause } \mathrm{CO}_{2} \text { emissions } \\
\text { but economic growth Granger } \\
\text { cause energy consumption }\end{array}$ \\
\hline 8 & Sbia et al. (2014) & UAE & 1975-2011 & $\begin{array}{l}\text { ARDL model and VECM } \\
\text { Granger causality }\end{array}$ & $\begin{array}{l}\text { A bidirectional causality } \\
\text { between } \mathrm{CO}_{2} \text { emissions and } \\
\text { economic growth, and a bidi- } \\
\text { rectional causality between } \\
\mathrm{CO}_{2} \text { emissions and energy } \\
\text { consumption }\end{array}$ \\
\hline 9 & Shahbaz et al. (2014) & UAE & 1975-2011 & ARDL model & $\begin{array}{l}\text { The EKC hypothesis exists in } \\
\text { the UAE. Economic growth } \\
\text { Granger cause } \mathrm{CO}_{2} \text { emis- } \\
\text { sions. A positive relationship } \\
\text { between urbanization and } \\
\mathrm{CO}_{2} \text { emissions }\end{array}$ \\
\hline 10 & Ozcan (2013) & 12 MENA countries & 1990-2008 & $\begin{array}{l}\text { Panel cointegration test and } \\
\text { the FMOLS }\end{array}$ & $\begin{array}{l}\text { Support the EKC hypothesis in } \\
\text { UAE, Egypt, and Lebanon }\end{array}$ \\
\hline 11 & $\begin{array}{l}\text { Alkhathlan and Javid } \\
\text { (2013) }\end{array}$ & Saudi Arabia & $1980-2011$ & ARDL and VECM models & $\begin{array}{l}\text { A bidirectional relationship } \\
\text { between } \mathrm{CO}_{2} \text { emissions and } \\
\text { economic growth }\end{array}$ \\
\hline 12 & Sweidan (2012) & UAE & 1973-2008 & ARDL model & $\begin{array}{l}\text { In the short run, a bidirectional } \\
\text { relationship between energy } \\
\text { consumption and real output. } \\
\text { In the long run, a unidirec- } \\
\text { tional relationship from real } \\
\text { output to energy consumption }\end{array}$ \\
\hline 13 & Alkhathlan et al. (2012) & Saudi Arabia & $1980-2008$ & ARDL and VECM models & $\begin{array}{l}\text { In the long run, output leads to } \\
\text { greater } \mathrm{CO}_{2} \text { emissions }\end{array}$ \\
\hline 14 & Mehrara (2007) & $\begin{array}{l}11 \text { oil exporting coun- } \\
\text { tries, including } 5 \text { GCC } \\
\text { countries }\end{array}$ & 1971-2002 & Panel cointegration & $\begin{array}{l}\text { A unidirectional from output to } \\
\text { energy consumption }\end{array}$ \\
\hline 15 & Squalli (2007) & OPEC members & 1980-2003 & ARDL model & $\begin{array}{l}\text { A bidirectional relationship } \\
\text { between energy consumption } \\
\text { and output }\end{array}$ \\
\hline 16 & Al-Iriani (2006) & The GCC countries & 1971-2002 & Panel cointegration & $\begin{array}{l}\text { A unidirectional from output to } \\
\text { energy consumption }\end{array}$ \\
\hline
\end{tabular}


In sum, our presentation proves that GCC countries have massive energy consumption and $\mathrm{CO}_{2}$ emissions. Simultaneously, the previous empirical works admit the importance of energy consumption to the GCC economy. They confirm significant links between energy consumption, economic growth, $\mathrm{CO}_{2}$ emissions, and environmental stress. Any random changes or unspecified policy action may adversely affect the economy and the environment. Hence, energy policy should be studied carefully in each country. These facts restrict the government maneuver to create genuine changes in economic policy and sustainability. However, we think that the GCC countries can adopt an efficient energy-environmental policy by taking more solid actions toward new technologies. It includes shifting to renewable energy, i.e., solar and wind. This shift helps the GCC countries diversify their energy resources and reduce fossil fuel's negative impacts. These countries have initiated some reforms, i.e., establishing research and development centers to enhance renewable energy deployment. It includes Masdar City in the United Arab Emirates (UAE) and King Abdullah City for Atomic and Renewable Energy in Saudi Arabia. It is useful to mention that UAE has initiated its nuclear energy program and built its first power plant in the region. It is expected to start working in 2020 (Al-Saidi and Haghirian, 2020). In the same vein, a recent strand of research in environmental economics, i.e., (Ma et al. 2020; Chen et al. 2020; Ma et al. 2019), provides assessment models and guidance for the governments on carbon emissions mitigation strategies to stimulate low-carbon communities.

\section{Government actions and policy framework}

Historically, the allocation state model has been controlling the economies of the MENA region. The role of the private sector in the economy is trivial because of the following reasons. First, the regional colonial powers have drawn national borders and formulated local governments. Thus, they become the legal heir of all economic and social decisions of the colonial power and tribal system (the patriarchy system). Second, the government is viewed as the primary provider of economic welfare and aids to its citizens, which is consistent with the Keynesian model. Third, the existence of global power, i.e., the former Soviet Union, who implemented the allocation state model as the principal performer in the economy. Fourth, the detection of gas and oil in the GCC states and the significant flow of the dollar revenues (Yousef 2004). Hence, one of the essential questions was how to allocate the generated income among the citizens? Like the other MENA countries, the GCC countries relied heavily on the command instruments rather than the marketbased instruments to allocate the resources. For example, the remedy for the market shortages was by supplying more goods and services, but not by adjusting the market prices.

Accordingly, the GCC different development plans adopted key policy targets and actions to guarantee sustainable economic development and protect the environment. Implicitly, these actions were trying to protect the environments via institutional arrangements and enhance the local private sector's contribution via economic diversification (Abdel Gelil 2017). Unfortunately, these policies did not succeed in achieving their goals. As a result, the GCC countries have moved closer to the market-based instrument via reforming the energy prices. Below, we discuss three key policy actions and institutional arrangements.

\section{Institutional arrangements and startup procedures}

The GCC countries have many cooperative institutional arrangements to support the environment and guarantee sustainable development. The GCC governments' development actions and policies have three different levels. First, the individual country level. Second, the GCC countries level via the GCC general secretariat. The GCC countries' organization structure is as follows: the supreme council, the ministerial council, and the secretariat general. Third, the League of Arab States via the economic and social council (Abdel Gelil 2017). The second and third levels are part of the cooperative framework among the GCC and the other Arab countries. Their goals are to enhance coordination, integration, and interconnection to achieve unity.

The Unified Economic Agreement of 1981 and 2001 assured that the GCC countries should harmonize their gas and oil industry policies, i.e., extraction, refining, marketing, processing, pricing, exploiting of natural gas, and development of the energy resources. Also, the member countries should develop standard oil policies and take common positions toward political matters that are of common concern to the GCC countries (GCC-SG 2014).

In 1985, the Supreme Council meeting in Muscat adopted policies and general rules to develop strategies for future environmental activities in the GCC States. We present, below, the most critical four policies and as follows (GCCSG 2014):

(1) Adopting a comprehensive concept of the environment. It includes all surrounding media such as water, air, land, and all elements therein, for instance, inanimate things, plants, animals, natural systems and processes, and human activities. (2) Establishing and completing the legislative and coordinating bodies, supporting the executive bodies in charge of implementing the regulations, rules, and standards of environmental protection, and providing observation and surveillance capabilities. (3) Promoting the community's awareness of environmental issues. Besides, fostering the sense of individual and collective responsibility 
for environment conservation. (4) Encouraging scientific research to identify environmental problems and preparing a directory of the available expertise in environmental protection.

Following the above-mentioned policies, the environmental ministers at the GCC countries have adopted the first action plan, which included the following goals:

(i) Surveying the environment protection bodies to identify their structures, organization, and powers. (ii) Identifying the familiar and similar environmental problems in the GCC States. (iii) Compiling and reviewing the environmental standards, laws, and legislation at the GCC States and making recommendations for completing and unifying them. (iv) Surveying the environment awareness programs in the various media and education at school curricula. (v) Utilizing the studies' results that are conducted by the regional and international organizations in this research area. These action plans succeeded in establishing around eleven environmental laws and standards. We report them, their goals, and place and year of approval in Table 5 .

The Ministerial Council meetings in 2007 and 2011 decided to establish the GCC Disaster Control Center and the Environmental Monitoring Center, respectively. The coordination among the GCC countries has motivated them to participate in around 24 international environmental conventions and agreements, i.e., Vienna 1985, Kyoto 1997, and Paris 2015. The GCC countries have initiated a historical interest in environmental safety, starting from the Vienna convention of 1985. The international initiations gave the GCC countries the motivation to establish and develop environmental legislation to comply with the international community.

The core question is, do all the mentioned policy actions are enough to generate an adequate understanding of environmental threats and effective environmental protection? The Arab Forum for Environment and Development (AFED) highlighted an answer to this question via its public opinion surveys. AFED conducted three surveys in 2006, 2009, and 2017, and their main conclusions are the same. AFED (2009) surveyed 19 Arab countries. All the GCC states were in the study sample and received 2322 responses. The survey aimed to discover the Arab public awareness of environmental threats because of climate change. The Arab countries are highly vulnerable to climate change impacts because they suffer water scarcity and recurrent drought. The survey found that $98 \%$ of the respondent believed that the climate is changing, $89 \%$ stated that it was due to human activities and excessive energy use, and $51 \%$ believed that the governments did not act sufficiently and effectively to address the problem. The survey concluded that no practical work is being executed to make the Arab countries prepared for climate change threats. There were no research efforts to examine the effects of climate change on health, food production, infrastructure, biodiversity, water, and tourism.

Table 5 Environmental laws and standards of the GCC countries. Source: GCC-SG (2014)

\begin{tabular}{|c|c|c|c|}
\hline No. & Law Name & Goal & Place and year of meeting \\
\hline 1 & The general environment protection law & $\begin{array}{l}\text { A comprehensive framework incorporating the basic } \\
\text { rules for environment conservation and protection }\end{array}$ & Muscat, 1995 \\
\hline 2 & $\begin{array}{l}\text { The common law for environmental assessment of } \\
\text { projects }\end{array}$ & $\begin{array}{l}\text { Observing the environmental impact of the various } \\
\text { projects }\end{array}$ & Muscat, 1995 \\
\hline 3 & The common law for protection of wildlife & $\begin{array}{l}\text { Developing legislation for the protection of wildlife, } \\
\text { planets, and animals }\end{array}$ & Kuwait, 1997 \\
\hline 4 & $\begin{array}{l}\text { The common law for handling radioactive sub- } \\
\text { stances }\end{array}$ & $\begin{array}{l}\text { Protecting man's health and environment from the } \\
\text { hazards of radiation and radioactive substances }\end{array}$ & Kuwait, 1997 \\
\hline 5 & The common law for waste management & $\begin{array}{l}\text { Protecting man's health and the various environmental } \\
\text { components from the hazards of the solid and toxic } \\
\text { waste }\end{array}$ & Kuwait, 1997 \\
\hline 6 & $\begin{array}{l}\text { Coordination of procedures among the GCC } \\
\text { countries }\end{array}$ & $\begin{array}{l}\text { Trans-border handling of hazardous waste for process- } \\
\text { ing, recycling, or disposal }\end{array}$ & Kuwait, 1997 \\
\hline 7 & $\begin{array}{l}\text { The common law for the management of hazard- } \\
\text { ous chemicals }\end{array}$ & $\begin{array}{l}\text { Controlling the practices of the Management of Haz- } \\
\text { ardous Chemicals }\end{array}$ & Muscat, 2001 \\
\hline 8 & $\begin{array}{l}\text { The common law for the management of health- } \\
\text { care waste }\end{array}$ & $\begin{array}{l}\text { Developing an adequate approach for controlling the } \\
\text { production, sorting, storage, handling, disposing, and } \\
\text { processing of healthcare waste }\end{array}$ & Muscat, 2001 \\
\hline 9 & $\begin{array}{l}\text { The environmental criteria and standards for the } \\
\text { quality of air and water }\end{array}$ & Identify the pollution levels & Manama, 2004 \\
\hline 10 & $\begin{array}{l}\text { The common reference law for controlling the } \\
\text { Ozone depleting materials }\end{array}$ & $\begin{array}{l}\text { Eliminate the use of Ozone depleting materials and } \\
\text { substituting }\end{array}$ & Abu Dhabi, 2005 \\
\hline 11 & $\begin{array}{l}\text { Approved five reference manuals in the field of } \\
\text { protection from radiation }\end{array}$ & $\begin{array}{l}\text { Protecting man's health and environment from radia- } \\
\text { tion and radioactive substances }\end{array}$ & Kuwait, 2009 \\
\hline
\end{tabular}


AFED (2017) resurveyed 22 Arab countries for the same purpose, all the GCC countries were in the study sample too, and it received 20,460 responses. The respondents said that the most critical environmental challenges are solid waste, weak environmental awareness, deterioration of water resources, pollution, and climate change. More than $60 \%$ of the respondents believed that the environment has deteriorated in their countries over the last ten years. Moreover, around 95\% think that their countries are not doing enough to tackle environmental threats. Respondents expressed their willingness to participate in environmental activities to protect the environment; $73 \%$ said they were ready to participate in environmental awareness campaigns, and $65 \%$ were fully prepared to comply with environmental legislation fully. Respondents believed that the primary causes of environmental deterioration were bad environment management, noncompliance with environmental legislation, weak environment institutions, and inadequate government spending on the environment. The survey indicated that respondents are calling their governments to place more tangible steps toward environmental protection. In sum, the GCC countries have established many institutional arrangements on different levels to enhance economic development and support environmental sustainability. However, the endeavors are not enough to comply with the announced goals in order to attain them.

\section{Economic diversification of the GCC countries}

Diversification in the GCC countries means vertical diversification, which is developing new economic sectors that encourages forward and backward linkages in the economy. A long time ago, the GCC countries realized that diversifying their economies away from the oil and gas sector is a strategic plan to overcome four major issues. First, gas and crude oil resources are finite, and their prices fluctuate considerably, which creates unstable income (Hvidt 2013). Recall that the government budget of each GCC state is connected with a fiscal break-even oil price in each year. Second, the extensive exploitation of natural resources, namely gas and crude oil, crowding out the other economic sectors. It is known in the literature by the Dutch disease. Therefore, diversifying the economy guarantees extra production and income. Third, economic diversification is an essential tool to face the challenges of climate change and preserve the environment. There is no doubt that climate change and global warming harm the different economic sectors, i.e., agricultural and tourism, specifically in fragile desert environments. Moreover, the current international efforts and procedures to combat greenhouse gas emissions and climate change may add more uncertainty to the GCC income (Al-Sarihi 2018). Fourth, economic diversification opens significant participation with the private sector; it guarantees more job opportunities for the national labor force (Hvidt 2013).

The GCC economies have begun to encourage entrepreneurs and small- and medium-sized enterprises as a potential initiative to diversify the economy, enhance economic growth, employment, and human and social development. However, the governmental efforts on this part are not enough to generate a thriving entrepreneurial ecosystem. (Tok 2018). The global ranking of global entrepreneurship and doing business indices of the GCC economies reveal a definite gap among these countries. The global entrepreneurship index (2019) is a multifaceted measure of the entrepreneurship ecosystem worldwide; it evaluates 14 components of the entrepreneurship ecosystem of 137 countries (Acs et al. 2019), while the World Bank report of doing business (2019) provides quantitative measures of business regulation in 11 regulatory areas central to how the private sector functions (World Bank 2019). Besides, there are definite shortcomings in front of the private sector to establish a private-owned business. Thus, the governments should develop broader strategies to improve the current situation. Economic diversification is still on the agenda of the economic development plans or the GCC countries' economic visions.

Did the economic diversification achieve its stated goals? We rely on historical data to answer this question via three indicators. First, we estimate the shares of the oil and non-oil sectors of the GCC countries during the period (1980-2017), as shown in Fig. 3. The relative importance of the gas and oil value-added has increased or stayed constant in most GCC countries. Second, we compute the relative importance of oil and gas revenues to each GCC country's GDP during the period (1980-2016). It is more accurate to use the ratio of the oil revenues to the government revenues, but the information is not available for all the GCC countries. We report the indicator in Fig. 4. It confirms the conclusion of Fig. 3 the oil revenues have almost a constant ratio to the GDP. The GCC economies' diversification achievements are weak; the ratio of the hydrocarbon sector to GDP is almost the same. Third, we compute the GCC counties' real GDP growth rates and oil prices during the period (1995-2019), as displayed in Fig. 5. Without a doubt, the two variables moving together, and the oil price growth rate leads economic growth rate. The above-mentioned evidence confirms that the GCC economies remain strongly influenced by the oil prices' movements, and the diversification achievements are weak.

Hvidt (2013) conducts an interesting study about the GCC economic diversification. His research covers the last five decades. He uses various textual references, reviews the development plans, performs field studies, and conducts close to a hundred interviews with planners 

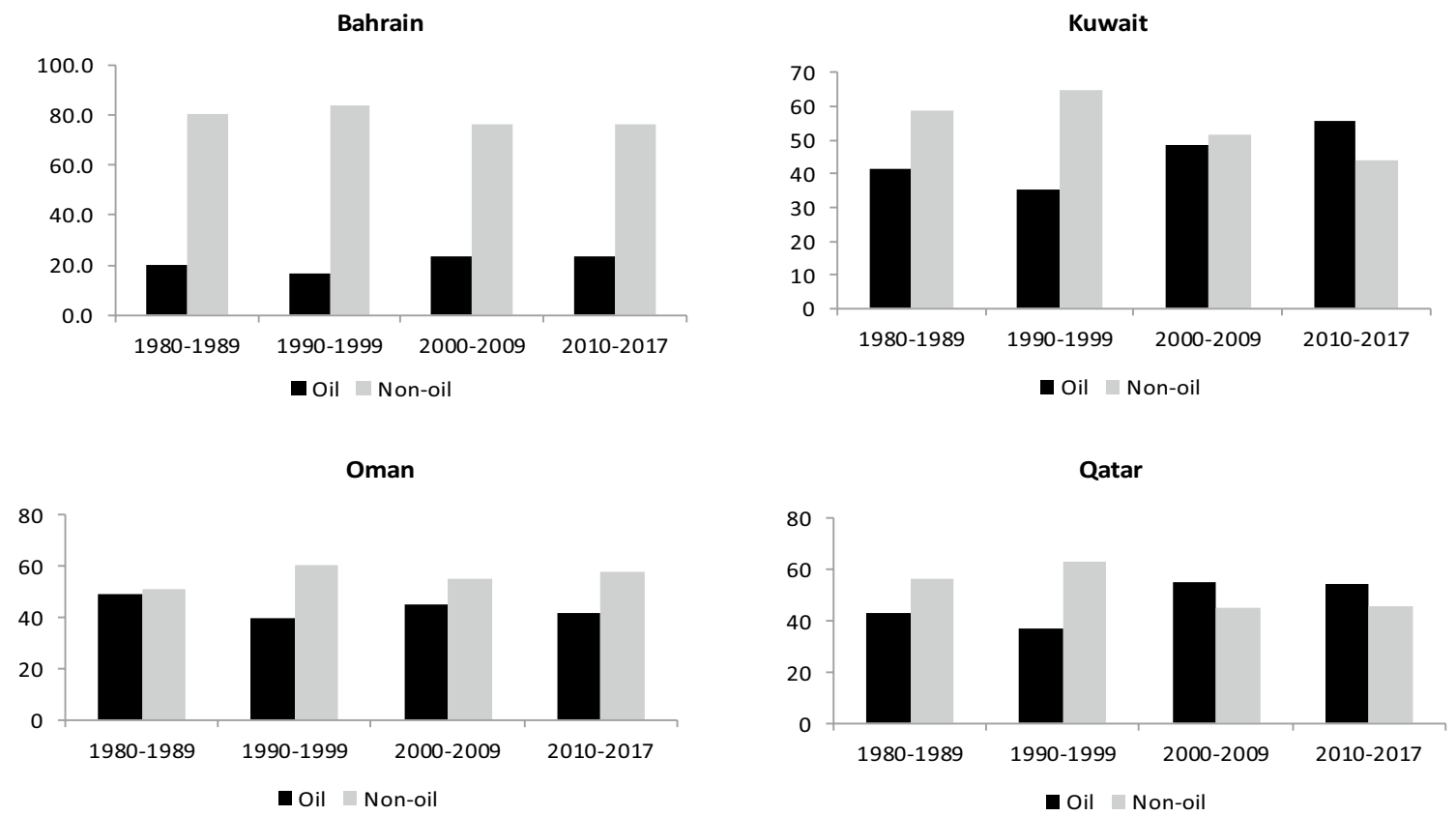

Saudi Arabia
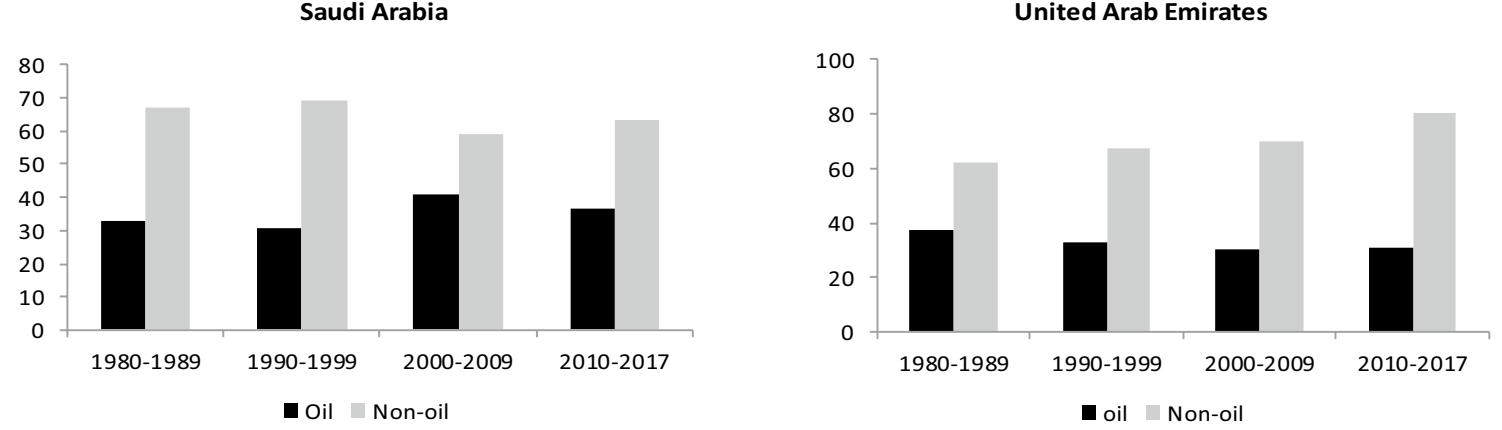

Fig. 3 The share of oil and non-oil sectors to GDP of the GCC countries. Source The national accounts for each country and Quandl website

and decision-makers. He concludes that the GCC countries have adopted necessary procedures to diversify their economies away from the gas and oil industry during the past five decades. Implicitly, the diversification core idea was to achieve a gradual and considerable move from the allocation state model to a more production-oriented model. The newly established model would encourage the private sector (including the citizens) and the government sectors to engage in the production of various goods and services. The government would rely on the proceeds from this new production to finance and create new economic cycles. As a result, the GCC governments established a first-class infrastructure, amended the health system, constructed a comprehensive educational system, and encouraged the private sector to engage in the production process. However, despite all the efforts, gas and oil remain the dominant sector in the GCC economies.

The GCC countries did not achieve significant progress in their economic diversification plans for five reasons. First, the institutional decisions to support diversification, as a strategic plan, negatively affected by oil prices; when the oil prices increased, the emphasis on economic diversification decreased.

Second, the GCC economies implement the allocation state model. Thus, moving to the production-oriented model needs fundamental institutional and political changes. Hvidt (2011) concludes that the institutional reforms before 2008 were initiated but not enough to shift the economy to the production-oriented model. Additionally, Hvidt (2013) calls the GCC economies to rely on strategic investments in economic assets, infrastructure, and education and execute more political, economic, and social reforms. Further, Seznec (2011) demonstrates that the development policies in the late 1970s relied primarily on import substitution as a tool for diversification. However, it was not entirely successful because of the competitiveness and the conflict of interest issues. There were clear trade-offs; if the local economy were to drive out imports, then the produced goods would 
Bahrain

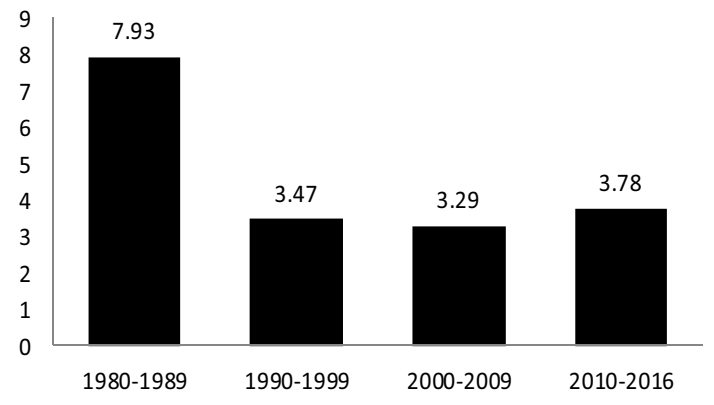

Oman

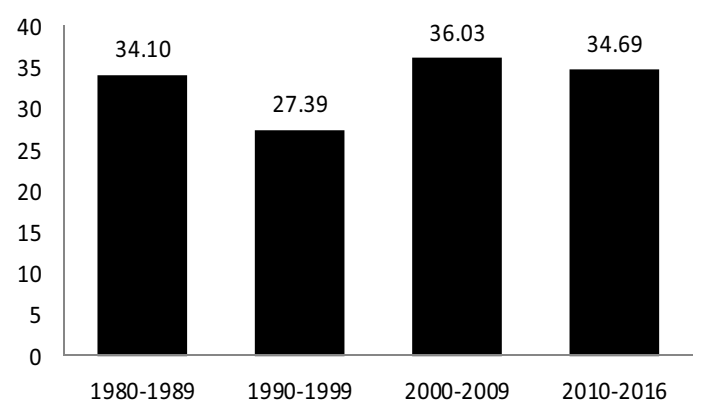

Saudi Arabia



Kuwait

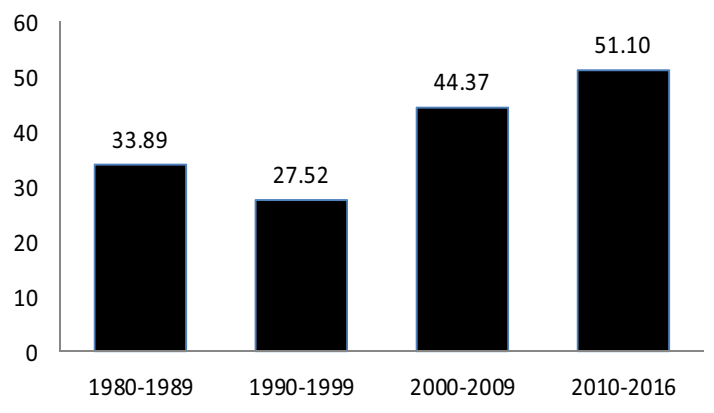

Qatar

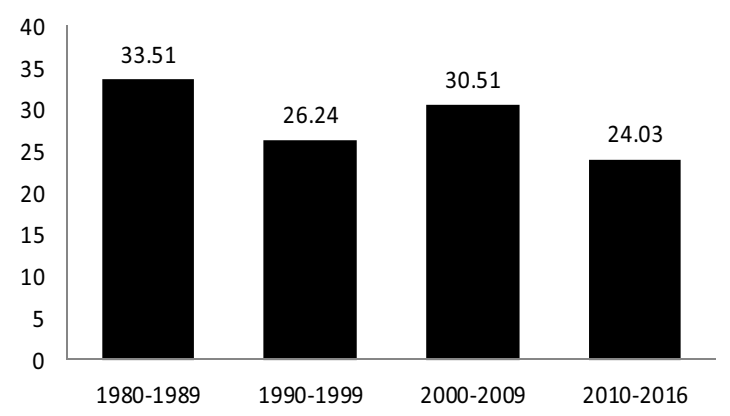

United Arab Emirates

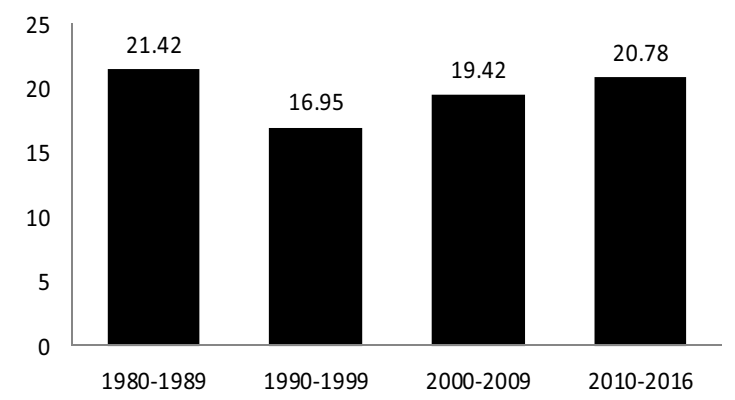

Fig. 4 The relative importance of oil and gas revenues to GDP of the GCC countries during the period (1980-2016). Source The global economy web site

Fig. 5 GCC RGDP growth rate and oil price growth rate during the period (1995-2019). Source World Bank Development Indicators Via the Data Stream




either have to be highly competitive, which is impossible or protected by very high tariff barriers. Adopting the import substitution strategy with high tariff barriers will decimate the merchant class (the elite), who have significant political power. Therefore, imposing high tariffs and substituting imports were challenging to be attained.

Third, the MENA region suffers continuous political instability a long-time ago, which harms economic growth (Sweidan, 2017). The GCC governments cannot proceed in their economic development plans if the region experiences wars and conflicts. Fourth, Looney (1994) points out several problems which are responsible for weak economic diversification in the GCC countries, i.e., lack of comprehensive diversification strategy, instability of the labor market because of the significant dependence on expatriate workers, unbalanced consumer perception, and the administrative bureaucracy (Hvidt 2013). Fifth, we cannot ignore the adverse effects of the world's economic crisis and coronavirus disease (COVID-19) pandemic on the success of economic diversification. The slowdown or the deterioration of the world economic growth implies a lower aggregate demand, lower oil prices, and a more much likelihood of protectionism.

\section{The energy price subsidy}

Historically, the price subsidy of energy and food is an integral part of the social contract in the GCC countries and the MENA region (Al-Saidi 2020). Subsidies have increased in response to commodity price increases, social demands, and political development in the GCC countries. Its primary direct mission is to support and protect households and businesses from oil price fluctuations. It is also a tool to redistribute the wealth created by the GCC countries' natural resource endowments to their citizens. Moreover, it contributes positively to political stability in the region during the past four decades. However, subsidies have adverse effects, i.e., encourage excessive energy consumption, weaken the current account, waste resources, enhance $\mathrm{CO}_{2}$ emissions, and exaggerated pollution. Further, cheap energy prices influence the economy structure by encouraging energybased technologies and capital-intensive industries, i.e., cement, petrochemicals, and fertilizers (IMF 2017b). The
International Monetary Fund (IMF) (2015a) estimates the cost of low energy prices in the GCC states for 2015, as foregone revenues, by around 5\% of the GDP.

The average relative importance of fossil fuel subsidy to the GCC countries' GDP is $6.5 \%$ during the period (2010-2014). The subsidy ratio to GDP started to decline in 2015. Thus, the average ratio of fossil fuel subsidy to the GDP decreased to 3.4\% throughout the period (2015-2018). The decline was trivial in some countries, i.e., Kuwait, from $6.5 \%$ in 2010 to $5.3 \%$ in 2018. However, it was remarkable in other countries, i.e., UAE, from $7.1 \%$ to $2.8 \%$ over the same period (IEA 2019). The drop is motivated by the remarkable deterioration in the oil prices in the mid of 2014. The oil price declined from $\$ 108.37$ per barrel in June 2014 to $\$ 29.78$ per barrel in January 2016. It caused governments budget deficits in the GCC countries during the period (2015-2019). On average, the actual oil price was below the fiscal breakeven oil price by around $\$ 19.16$ per barrel during the period (2015-2019). Fiscal consolidation, i.e., imposing taxes and energy price reforms, was to re-balance the government budget and the economy.

Table 6 presents the major fiscal reforms across GCC countries. In 2015, the GCC countries adjusted upward of electricity tariffs and local fuel prices (petroleum products and natural gas) considerably by reducing or eliminating the price gaps. The UAE has eliminated the energy subsidy, while the other GCC countries have initiated the reform, but the subsidy remains (IMF 2017b). The IMF (2017a) stated that the energy subsidies in the GCC have fallen from $\$ 116$ billion in 2014 to $\$ 47$ billion in 2016.

The previous experience says not all the subsidy reforms attained their announced goals. The IMF (2013) explores the practice of 22 countries in the area of energy price reforms over 28 reform episodes. The goal of the study was to provide insights from country case studies to identify ingredients for successful subsidy reform. It finds that only 12 episodes were classified as a success, 11 partially or fully lost the reform gains over time, and five did not succeed. It also finds many barriers to successful subsidy reform: the adverse impact on the poor is unknown, and weak macroeconomic conditions; the resistance to the reform is lower when economic growth is relatively high, and inflation is low. The IMF (2013 and 2017b) proposes some critical messages for
Table 6 Summary of major fiscal reforms across the GCC countries. Source: Young (2018)

\begin{tabular}{lllllll}
\hline & Bahrain & Kuwait & Oman & Qatar & Saudi Arabia & UAE \\
\hline Value add tax of 5\% & & & & $\checkmark$ & $\checkmark$ \\
Excise taxes & $\checkmark$ & & & $\checkmark$ & $\checkmark$ \\
Electricity and water tariff & $\checkmark$ & $\checkmark$ & $\checkmark$ & $\checkmark$ & $\checkmark$ & $\checkmark$ \\
Transportation fuel prices (tax) & $\checkmark$ & $\checkmark$ & $\checkmark$ & $\checkmark$ & $\checkmark$ & $\checkmark$ \\
\hline
\end{tabular}


a successful energy price reform based on the experience from different countries: construct a comprehensive reform plan and communicate with the public.

The question is, can the GCC economies succeed in their agendas of energy price reform? Undoubtedly, it may be a good chance for the GCC countries to depend on the market mechanism as a resource allocator, which will help to reduce the waste resources. However, there are many concerns about this policy. First, the energy reform policy's primary motive is not to adjust the historical distortion in the local energy prices but to face a significant challenge related to the government budget deficit. Therefore, we may expect a termination for these reforms if the oil prices adjusted upward. The previous experience supports our statement; in 1950, Saudi Arabia introduced personal income, capital gains, and corporate taxes on nationals and non-nationals, but taxes were suspended due to high oil revenues and the need to recruit expatriates to develop the economy (IMF 2015b).

Second, the reforms were established under weak macroeconomic conditions; the economic growth is slowing down during the period (2015-2019), and some countries, i.e., Kuwait, Oman, and Saudi Arabia, registered negative economic growth rates during that period. More importantly, real GDP in the region is expected to fall by $4.1 \%$ in 2020 because of COVID-19 (IMF 2020). Third, the reform policy may adversely affect the competitiveness of the energy-intensive sectors, which are leading sectors in the GCC countries. The IMF (2015a) expects a manageable impact on industrial activity and an adverse effect on energy-intensive industries. However, it expects significant permanent real income gains for the economy in the long run.

Fourth, the effect on the poor is not determined. The IMF (2015a) predicts that the energy price reforms would generate a small inflationary influence in the GCC economies because the energy products have a low weight in the consumer price index (CPI). We think that the weights reported in the IMF (2015a) are not the actual weights because they should be adjusted to exclude the subsidy. Besides, energy is an input in all the sectors of the economy, which means it has a magnification effect. Fifth, none of the GCC countries proposed measures in the reform strategies to protect the poor except Saudi Arabia (IMF 2017b). The IMF (2013) finds that $65 \%$ of the 28 reform episodes relied on targeted mitigating measures: cash transfers and social programs. The ratio of expatriates to the total population in the GCC states is around $48.1 \%$. A large portion of this group is poor workers with low wages. Hence, the price energy reform may influence this group harshly. A safety net should cover this group of poor expatriate workers because of their relative importance in the economy.

\section{Moving to the market-based model or changing the government role}

The GCC governments' policies did not achieve significant progress in their announced goals in sustainable economy and environmental protection over the past five decades. The above-mentioned evidence of the current paper supports our conclusion. The current paper mentions many challenges and obstacles, which were constraints to accomplish the various declared objectives. However, we raise a core and logical question about the desire of the GCC governments to create a complete change in the area of sustainable economics? We ask this question because the GCC governments, historically, were the major players in their economies. Implicitly, the economic diversification and the energy price reforms imply moving to the market-based model. Therefore, our specific concern is, do the GCC governments are serious about moving closer to the traditional market-based model, or is it changing the role? Answering this question is significant because it highlights the interconnection between economic decisions and political decisions. Accordingly, the improvement in the SCP pattern can be initiated by a political decision.

Adopting economic reform to be closer to the free market economy has a cost. It reconfigures the social contract or the relationship between the citizens and the state. It implies renegotiating the benefits to citizens, i.e., subsidies, health, and education services. Also, there will be taxes and extra fees and duties. More political rights and freedom should accompany the movement toward the new situation. If these costs are high to the political regime, then the adjustment process may be slow, or the political regime may cancel it and bring a new solution. Thus, the institutional economists, i.e., (Acemoglu and Robinson, 2008; Dixit, 2007), agree that the economic reforms depend primarily on the nature of the political regime. We, therefore, agree with Tok (2018) that the primary interest of the GCC countries is regime security.

There are three factors responsible for reducing the speed of economic reforms in the MENA region, including the GCC countries. These factors are: First, the nature of the political regimes; minimal progress in democratic and public accountability institutions means a lower desire to change. Second, the persistence of political instability, conflict, and violence; the more political instability indicates the lower desire to perform the required reforms. This factor can be achieved by diverting resources to military expenditures, increasing risk aversion to reforms, and changing the political regime's priorities. Third, oil and gas revenues affect the reforms directly via reducing the incentives to undertake reforms and indirectly via influencing the public sector accountability and efficiency (Nabli et al. 2008). On the other side, the neo-liberal economic policies, which the US 
and the IMF suggested, had damaged the MENA economies. Thus, it reduces the trust in the free market policies as a resource distributor (Turan 2018).

We believe that the GCC governments have established a hybrid model through the adjustment process. Some researchers, i.e., Bremmer 2009; Gray 2011, point out establishing the "Entrepreneurial State Capitalist" in the GCC region starting from the 1990s. Gray (2011) considers it one of the features of the rentier state theory, a political economy theory that seeks to understand statesociety relations in states that generate a large proportion of their income from rents, i.e., oil revenues. According to Bremer (2009), state capitalism started in 1973 during the Arab oil embargo. He determines four waves of state capitalism. The last wave was started by the great recession (2007-2009) and led by the industrial countries' lawmakers. Meanwhile, Alami and Dixon (2020) mention some signs of the State Capitalism rise. It includes bailing out the financial systems following the 2008 financial crisis and expanding state-owned enterprises and sovereign wealth funds. It means that the role of the government has been changed. It moves from managing, dominating, and approving economic policies to set strategic goals, visions and engage in the production process internally and externally by state-owned businesses.

The governments' role has evolved for many reasons, i.e., state maturity, secure the regime, globalization, and development policies. Examples of the state-owned businesses in the UAE, a significant portion of Dubai's largest firms, are state-owned businesses, i.e., Dubai World and Dubai Holding. In Saudi Arabia, the Saudi Basic Industries Corporation (SABIC) and the National Commercial Bank. Other businesses across the GCC countries include airlines and telecommunications companies. Moreover, the GCC governments prefer a particular type of private sector to support the state and its state capitalist structure. Those businessmen belong to the political elite, merchant families, other wellconnected individuals, and sometimes some foreign businesspeople (Gray 2011). State capitalism has four leading players: national oil corporations, state-owned firms, sovereign wealth funds, and privately owned national champions (the preferred type of private sector). The sovereign wealth funds are used to finance state-owned businesses (Bremmer 2009). As a result, establishing a private sector working with the market mechanism philosophy will be weak.

The above-mentioned analysis shows that the adjustment toward the free market economy in the GCC countries has a high cost. The governments of the region are trying to achieve their goals with the minimum cost. The new solution guarantees that the government will stay the most influential player in the economy, and thus the regime can be secured.

\section{Conclusions and policy implication}

The GCC countries rely heavily on the hydrocarbon sector as a primary source of income. High population growth rate, economic growth rate, low domestic energy prices, and water desalination have motivated the high energy consumption in the region. The data prove the enormous energy consumption and $\mathrm{CO}_{2}$ emission per capita of the region. Meanwhile, the oil revenues contribute positively to economic development and public welfare in the GCC countries. The quantitative studies acknowledge the importance of energy consumption to the GCC economy. They also confirm significant connections between energy consumption, economic growth, $\mathrm{CO}_{2}$ emissions, and environmental stress. These findings display a significant trade-off between economic growth and a clean environment.

Therefore, we review three core governments' policies in this research area. First, institutional arrangements to protect the environment. Second, economic diversification policy to enhance the private sector's contribution to the economy. Third, energy price reforms. These policies are vital because they play a significant role in creating a balance between achieving permanent economic growth and preserve the environment. The current paper employs the analytical approach and uses data, remarks, and outcomes of the previous studies to expand the knowledge and extract conclusions. Our analysis shows that the GCC countries' institutional actions were not enough to generate adequate environmental protection. The GCC economies remain strongly influenced by oil and gas price fluctuations, and the diversification achievements are weak. Moreover, the GCC governments adopt comprehensive fiscal reforms, including energy price reforms, to support the governments' budget and restrict energy consumption. Nevertheless, there are several concerns about this policy.

Besides, we find many challenges that influenced the GCC economies during the steps to enhance the SCP. The major challenge is the role of the government in the economy. The GCC governments are building their hybrid private sector under the concept of entrepreneurial state capitalist. Under this new concept, the governments formulate, regulate, and dominate the private sector to secure the regimes.

The above-mentioned findings lead to significant policy implications. The purpose of these policies is to adjust the current situation and support the sustainability of consumption and production. The GCC countries should revive the process of diversifying the economy on actual actions, besides enhancing the movements toward the free market economy by abolishing the distortions in the prices, mainly in the energy sector. Furthermore, these countries should implement an efficient energy-environmental policy by 
enhancing more concrete actions toward new technologies. It includes shifting to renewable energy, i.e., solar and wind.

Acknowledgements We would like to thank the editor and four anonymous referees of Clean Technologies and Environmental Policy for their valuable and helpful comments. We are responsible for any remaining errors.

Authors' contributions This paper has a single author.

Funding There is no funding for this work.

Data availability All the data are inside the paper.

\section{Declarations}

Conflicts of interest The authors declare that they have no conflict of interest.

\section{References}

Abdel Gelil I (2017) Environmental policy framework. In: Saab N (ed) Arab environment in 10 years. Annual report of Arab forum for environment and development; Saab N (ed) pp 31-62, Beirut, Lebanon. Technical Publications

Acemoglu D, Robinson J (2008) The role of institutions in growth and development. Growth commission working paper no. 10, World Bank

Acs ZJ, Szerb L, Lafuente E, Márkus G (2019) The global entrepreneurship index. The global entrepreneurship and development institute, Washington, D.C., USA. doi: https://doi.org/10.13140/ RG.2.2.17692.64641

AFED (2006) Arab public opinion and the environment conference report of 18 country survey. Beirut, Lebanon, 16-17 June.

AFED (2008) Arab environment: future challenges. Annual report of Arab forum for environment and development. In: Tolba M, Saab $\mathrm{N}$ (eds) Beirut, Lebanon. Technical Publications

AFED (2009) Arab environment: climate change. Annual report of Arab forum for environment and development. In: Tolba M, Saab $\mathrm{N}$ (eds) Beirut, Lebanon. Technical Publications

AFED (2017) Arab environment in 10 years. Annual report of Arab forum for environment and development. In: Saab N (ed) Beirut, Lebanon. Technical Publications

Alami I, Dixon AD (2020) The strange geographies of the 'new' state capitalism. Polit Geogr 82, forthcoming. doi: https://doi.org/10. 1016/j.polgeo.2020.102237

Al-Iriani MA (2006) Energy-GDP relationship revisited: an example from GCC countries using panel causality. Energy Policy 34(17):3342-3350. https://doi.org/10.1016/j.enpol.2005.07.005

Al-Iriani MA, Trabelsi M (2015) The economic impact of phasing out energy consumption subsidies in GCC countries. J Econ Bus 87:35-49. https://doi.org/10.1016/j.jeconbus.2016.04.004

Alkhathlan K, Javid M (2013) Energy consumption, carbon emissions and economic growth in Saudi Arabia: an aggregate and disaggregate analysis. Energy Policy 62:1525-1532. https://doi.org/10. 1016/j.enpol.2013.07.068

Alkhathlan K, Alam M, Javid M (2012) Carbon dioxide emissions, energy consumption and economic growth in Saudi Arabia: a multivariate cointegration analysis. British Br J Econ Manage Trade 2(4):327-339

Al-Mulali U, Ozturk I (2015) The effect of energy consumption. urbanization, trade openness, industrial output, and the political stability on the environmental degradation in the MENA region. Energy 84:382-389. https://doi.org/10.1016/j.energy.2015.03.004

Al-Saidi M (2020) Instruments of energy subsidy reforms in Arab countries - the case of the Gulf Cooperation Council (GCC) countries. Energy Rep 6:68-73. https://doi.org/10.1016/j.egyr.2019.08.020

Al-Saidi M, Haghirian M (2020) A quest for the Arabian atom? Geopolitics, security, and national identity in the nuclear energy programs in the middle east. Energy Res Soc Sci, 68. Forthcoming. doi: https://doi.org/10.1016/j.erss.2020.101582

Al-Sarihi A (2018) Prospects for climate change integration into the GCC economic diversification strategies. LSE Middle East Center. Paper series 20, February

Baker S (1996) Sustainable development and consumption: The ambiguities - the Oslo ministerial roundtable conference on sustainable production and consumption, Oslo, 6-10 February 1995. Environ Polit 5(1):93-99. https://doi.org/10.1080/09644019608414249

Baumgartner S, Quaa M (2010) What is sustainability economics? Ecol Econ 69:445-450. https://doi.org/10.1016/j.ecolecon.2009.11.019

Bengtsson M, Alfredsson E, Cohen M, Lorek S, Schroeder P (2018) Transforming systems of consumption and production for achieving the sustainable development goals: moving beyond efficiency. Sustain Sci 13(6):1533-1547. https://doi.org/10.1007/ s11625-018-0582-1

Bremmer I (2009) State capitalism comes of age. Foreign Affairs 88(3):40-55

British Petroleum (2020) BP statistical review of the world energy, 69th edn.

Chen L, Cai W, Ma M (2020) Decoupling or delusion? Mapping carbon emission per capita based on the human development index in Southwest China. Sci Total Environ 741:138722. https://doi.org/ 10.1016/j.scitotenv.2020.138722

Dixit A (2007) Evaluating recipes for development success. The World Bank Research Observer 22(2):131-157

GCC-SG (2014) GCC the process and achievements, $8^{\text {th }}$ edn, General secretary, division of information affairs, Riyadh, Saudi Arabia.

Gray M (2011) A theory of late rentierism in the Arab States of the Gulf. Center for international and regional studies 7. Doha: Georgetown University School of Foreign Service in Qatar.

Hvidt M (2011) Economic and institutional reforms in the Arab Gulf Countries. Middle East J 65(1):85-102. https://doi.org/10.3751/ 65.1 .15

Hvidt M (2013) Economic diversification in GCC countries past record and future trends, research paper, Kuwait Programme on development, governance and Globalisation in the Gulf States.

IEA (2019) The IEA's World Energy Outlook 2019. The International Energy Agency. https://www.iea.org/weo.

IMF (2013) Energy subsidy reform: lessons and implications, January. International monetary fund, Washington DC, USA.

IMF (2015a) Energy price reforms in the GCC - what can be learned from international experiences? International monetary fund annual meeting of ministers of finance and central bank governors, Doha, Qatar, November.

IMF (2015b). Tax policy reforms in the GCC countries: Now and how? International monetary fund annual meeting of ministers of finance and central bank governors, Doha, Qatar, November.

IMF (2017a) The economic outlook and policy challenges in the GCC countries, December. International Monetary Fund, Washington DC, USA.

IMF (2017b) If not now, when? energy price reform in Arab countries. The international monetary fund, annual meeting of Arab ministers of finance, Rabat, Morocco, April.

IMF (2020) The regional economic outlook: Middle East and Central Asia, October. International Monetary Fund, Washington DC, USA.

IPCC (2018) Global Warming of $1.5^{\circ} \mathrm{C}$. An IPCC Special Report on the impacts of global warming of $1.5^{\circ} \mathrm{C}$ above pre-industrial levels and related global greenhouse gas emission pathways. 
Kais S, Sami H (2016) An econometric study of the impact of economic growth and energy use on carbon emissions: Panel data evidence from fifty eight countries. Renew Sust Energy Rev 59:1101-1110. https://doi.org/10.1016/j.rser.2016.01.054

Looney RE (1994) Industrial development and diversification of the Arabian Gulf economies. JAI Press, Greenwich, CT

Ma M, Ma X, Cai W, Cai W (2019) Carbon-dioxide mitigation in the residential building sector: A household scale-based assessment. Energy Convers Manage 198:111915. https://doi.org/10.1016/j. enconman.2019.111915

Ma M, Ma X, Cai W, Cai W (2020) Low carbon roadmap of residential building sector in China: Historical mitigation and prospective peak. Appl Energy 273:115247. https://doi.org/10.1016/j.apene rgy.2020.115247

Mahmood H, Alkhateeb TTY, Furgan M (2020) Industrialization, urbanization and $\mathrm{CO}_{2}$ emissions in Saudi Arabia: Asymmetry analysis. Energy Rep 6:1553-1560. https://doi.org/10.1016/j. egyr.2020.06.004

Mehrara M (2007) Energy consumption and economic growth: the case of oil exporting countries. Energy Policy 35(5):2939-2945. https://doi.org/10.1016/j.enpol.2006.10.018

Muhammed B (2019) Energy consumption, $\mathrm{CO}_{2}$ emissions and economic growth in developed, emerging and Middle East and North Africa countries. Energy 179:232-245. https://doi.org/10.1016/j. energy.2019.03.126

Nabli MK, Silva-Jáuregui C, Aysan AF (2008) Political authoritarianism, credibility of reforms and private sector development in the Middle East and North Africa. Revue D'économie Du Développement 16(5):5-36. https://doi.org/10.3917/edd.225.0005

Ozcan B (2013) The nexus between carbon emissions, energy consumption and economic growth in Middle East countries: a panel data analysis. Energy Policy 62:1138-1147. https://doi.org/10. 1016/j.enpol.2013.07.016

Sabapathy J (2007) Sustainable consumption and production. Cambridge University, London, Cambridge Programme for Industry

Salahuddin M, Gow J (2014) Economic growth, energy consumption and $\mathrm{CO}_{2}$ emissions in Gulf Cooperation Council countries. Energy 73:44-58. https://doi.org/10.1016/j.energy.2014.05.054

Sbia R, Shahbaz M, Hamdi H (2014) A contribution of foreign direct investment, clean energy, trade openness, carbon emissions and economic growth to energy demand in UAE. Econ Model 36:191197. https://doi.org/10.1016/j.econmod.2013.09.047

Sbia R, Shahbaz M, Ozturk I (2017) Economic growth, financial development, urbanisation and electricity consumption nexus in UAE. Econ Res-Ekon Istraz 30(1):527-549. https://doi.org/10.1080/ 1331677X.2017.1305792

Seznec J-F (2011) Introduction. In: Seznec J-F, Kirk M (eds) Industrialization in the Gulf: a socioeconomic revolution. London: Center for Contemporary Arab Studies, Georgetown University/ Routledge, pp 1-14

Shahbaz M, Sbia R, Hamdi H, Ozturk I (2014) (2014) Economic growth, electricity consumption, urbanization and environmental degradation relationship in United Arab Emirates. Ecolo Indic 45:622-631. https://doi.org/10.1016/j.ecolind.2014.05.022

Squalli J (2007) Electricity consumption and economic growth: bounds and causality analyses of OPEC countries. Energ Econ 29(6):1192-1205. https://doi.org/10.1016/j.eneco.2006.10.001

Sweidan OD (2012) Energy consumption and real output: evidence from the UAE economy. OPEC Energ Rev 36(3):287-300. https:// doi.org/10.1111/j.1753-0237.2012.00213.x

Sweidan OD (2017) The influence of political regime vs. political instability on real output: evidence from the MENA region. J Econ Stud 44(1):154-167. https://doi.org/10.1108/JES-12-2015-0225

Sweidan OD (2018) Economic performance and carbon intensity of human well-being: empirical evidence from the MENA region. $\mathrm{J}$ Environ Plann Man 61(4):699-723. https://doi.org/10.1080/09640 568.2017.1332986

Sweidan OD, Alwaked AA (2016) Economic development and the energy intensity of human well-being: evidence from the GCC countries. Renew Sust Energ Rev 55:1363-1369. https://doi.org/ 10.1016/j.rser.2015.06.001

Tiba S, Omri A (2017) Literature survey on the relationships between energy, environment and economic growth. renewable and sustainable energy reviews 69:1129-1146. Renew Sust Energ Rev 69:1129-1146. https://doi.org/10.1016/j.rser.2016.09.113

Tok M E (2018) Can GCC states achieve sustainable economic diversification and development. Center for the Middle East, Rice University's Baker Institute for Public Policy.

Turan T (2018) The UN's response to the underlying causes of the Arab Spring before and after the eruption of events: a critical assessment of the UN's pursuit of its core values and purposes. Middle Eastern Stud 54:683-705. https://doi.org/10.1080/00263 206.2018.1448791

Walsh P P, Murphy E, Horan D (2020) The role of science, technology and innovation in the UN 2030 agenda. Technol Forecast Soc 154, forthcoming. doi: https://doi.org/10.1016/j.techfore.2020.119957.

Wei Y, Zou Q-P, Lin X (2021) Evolution of price policy for offshore wind energy in China: Trilemma of capacity, price and subsidy. Renew Sust Energ Rev 136. Forthcoming. doi: https://doi.org/10. 1016/j.rser.2020.110366.

World Bank (2019) Doing business 2019: Training for reform. $16^{\text {th }}$ Edition. The World Bank, Washington DC, USA.

Young K E (2018) The difficult promise of the economic reform in the Gulf. Center for the Middle East, Rice University's Baker Institute for Public Policy.

Yousef TM (2004) Development, growth and policy reform in the Middle East and North Africa Since 1950. J Econ Perspect 18:91-116. https://doi.org/10.1257/0895330042162322

Publisher's Note Springer Nature remains neutral with regard to jurisdictional claims in published maps and institutional affiliations.

\section{Authors and Affiliations}

\section{Osama D. Sweidan ${ }^{1}$}

Osama D. Sweidan

osweidan@uaeu.ac.ae

1 Department of Innovation in Government and Society, United Arab Emirates University, P.O. Box 15551, Al-Ain, UAE 